To the best of my knowledge we are the first maxillofacial unit to implement the use of such a checklist and Barts and the London NHS Trust has recently followed our example. I strongly feel that this is a milestone in ensuring patient safety and should be instituted by all maxillofacial units and even dental surgeries to improve quality of care.

S. Duggineni, by email DOI: 10.1038/sj.bdj.2011.345

\section{NOT ESTABLISHED}

Sir, I am writing in response to the letter in the BDJ titled Undermining consent by J. Mew (BDJ 2011; 210: 52).

I would like to say that the so called orthotropics is not an established form of treatment for malocclusion. It is presently neither being taught to postgraduate trainees in orthodontics nor is it recommended as an option of treatment by the NHS. So the question of undermining of consent doesn't arise at all.

Z. Imran, Dundee

DOI: 10.1038/sj.bdj.2011.346

\section{FRAUGHT WITH DANGER}

Sir, I agree with Bob Chate (Dental appliances with inadequate occlusal coverage; $B D J$ 2011; 210: 109-110) that it can be dangerous to use part coverage splints but even the full coverage splints and intrusion wires he recommends have their dangers. A broad band of evidence tells us that in the long-term changing the occlusion usually reduces muscle tone, weakens lip seal, and increases vertical height ${ }^{1,2}$ and an equally broad band suggests that this in turn may reduce arch length, worsen dental crowding and increase the risk of TMD or sleep apnoea. ${ }^{3-6}$ Adjusting the occlusion is fraught with danger.

In one way it is simple: all dentists know that unopposed teeth continue to erupt. Why then don't all patients have full occlusal contact; surely the contact should self correct? The answer is 'not unless the teeth are in contact enough'. The correct balance seems to be four to eight hours of light contact in 24 which will ensure an ideal occlusal height for all humans. ${ }^{7}$ The complex bit is generating enough muscle tone to restore a satisfactory occlusion; there is no other way.
If the muscle tone is weak the teeth over-erupt, premature contacts develop and bite splints fail to work unless they are five or more millimetres high, which risks permanent facial lengthening. As a result of weak muscle tone most civilised humans have their maxilla ten or more millimetres too far down and back from its ideal relationship with the cranial vault. If this is not corrected before the child is 9-years-old they will be stuck with palliative treatment and life-long retention.

\section{J. Mew, by email}

1. Battagel J M. The use of tensor analysis to investigate facial changes in treated Class II division 1 malocclusions. Eur J Orthod 1996; 18: 41-54.

2. Benington P C M, Hunt N P. Masseter muscle volume and craniofacial morphology. Br J Orthod 1994; 21: 407-408.

3. Bondemark L. Does two years nocturnal treatment with a mandibular advancement splint in adult patients with OSAS cause a change in the posture of the mandible? Am J Orthod Dentofacial Orthop 1999: 116: 621-628.

4. Franchi L, Baccetti T, Sacerdoti R, Tollaro I. Dentofacial features associated with crowding of the lower incisors. Eur J Orthod 1997: 19: 570.

5. Iscan H N, Sarisoy L. Comparison of the effects of posterior bite-blocks with different construction bites, on the craniofacial and dentoalveolar structures. Am J Orthod Dentofacial Orthop 1997; 112: 171-178.

6. Almeida F R, Lowe A A, Sung J 0, Tsuiki S, Otsuka R. Long-term sequellae of oral appliance therapy in obstructive sleep apnea patients: Part 1. Cephalometric analysis. Am J Orthod Dentofacial Orthop 2006; 129: 195-204.

7. Lee C F, Proffit W R. The daily rhythm of tooth eruption. Am J Orthod Dentofacial Orthop 1995; 107: $38-47$

DOI: $10.1038 /$ sj.bdj.2011.347

\section{STILL GOING STRONG}

Sir, I enjoyed the recent $B D J$ article on John Ruskin and Alfred James Woodhouse and Mr Bishop's interesting research (BDJ 2011; 210: 179-182).

Then at the end (Dental postscript 2) I was excited (!) to see my old practice mentioned. I wrote a history published in Dental Historian no. 31: November 1996 entitled 'Frederick Bullin (18331904) and White Friars House, Chester'.

The practice is still going strong but I have no access, of course, to any old records - perhaps to see what Mrs La Touche may have been charged!

\section{J. R. Davey, Chester}

DOI: 10.1038/sj.bdj.2011.348

\section{RANCID NUTS}

Sir, I have just read R. Hampton's letter about a patient suffering from pine mouth (BDJ 2011; 210: 151). I have also been suffering from the same thing. I started suffering from a bitter aftertaste while and after eating or drinking. This was really concerning me so I googled 'bitter taste' and was relieved and surprised to find many articles about pine mouth. I had eaten a pine nut salad with pasta and pesto on 13 March at a party I held for my son. As there was some of this salad left over I ate the remainder over the next couple of days. On 15 March I didn't like the taste of the salad so discarded the remains but was left with a slight aftertaste for the rest of the day. The next day just over 24 hours later everything started to taste awful, really bitter. I still had the bitter taste nearly a week later but it is gradually improving. I do not know whether the pine nuts came from China as the dish was ordered from a supermarket catering service. I do feel, however, that the nuts were possibly turning rancid when I ate them after the party date as they were in an oily pesto and parmesan sauce. Unfortunately I think I have overdosed on pine nuts which I will never eat again. It is of concern, as you feel that your system has been temporarily poisoned.

S. Buchanan, by email DOI: 10.1038/sj.bdj.2011.349

\section{PRICELESS}

Sir, an email to my single-handed practice from the CQC (Creating Quality Comedy) regarding the fees ended with the hilarious 'Please ensure this comes to the notice of your Finance Dept'.

Having put up extra shelving to cope with all the files, folders and papers needed to comply with the CQC, we were then doubled up with laughter at 'Think before you print' at the bottom of the email. Priceless!

K. Smith, Quorn

DOI: $10.1038 /$ sj.bdj.2011.350 